\title{
Efektivitas Muhasabah dan Tafakur Alam Terhadap Penurunan Tingkat Stres pada Mahasiswa Tingkat Akhir
}

\author{
Andriyani \\ Program Studi Kesehatan Masyarakat, Fakultas Kedokteran dan Kesehatan, Universitas Muhammadiyah Jakarta \\ Jl. KH. Ahmad Dahlan, Ciputat, Cirendeu, Banten 15419 \\ Email: drandriyanimag@gmail.com
}

\begin{abstract}
ABSTRAK
Skripsi bagi mahasiswa adalah suatu kewajiban yang harus diselesaikan, namun skripsi tidaklah semudah mengerjakan makalah ataupun tugas-tugas mata kuliah pada umumnya. Banyak hal yang dapat menjadi kendala untuk mampu menyelesaikan skripsi, sehingga membuat mahasiswa merasa terbebani dan menjadi stres. Penelitian ini menggunakan desain studi quasi eksperimental. Sampel merupakan mahasiswa tingkat akhir yang telah menyusun skripsi yaitu mahasiswa Program Studi Kesehatan Masyarakat sebanyak 38 orang mahasiswa. Alat penelitian berupa Kuesioner DASS (Depression Anxiety Stress Scale) dan dianalisis menggunakan paired t test. Hasil penelitian menemukan adanya perbedaan nilai mean antara sebelum dan sesudah dilakukan muhasabah dan tafakur alam yaitu muhasabah dengan nilai mean 21,789 dengan standar deviasi 14,148 dan "Sig (2-tailed)" yaitu $\mathrm{p}=0,000$. Begitu juga dengan tafakur alam, ada perbedaan nilai mean antara sebelum dan sesudah dilakukan tafakur alam yaitu 21,211 dengan standar deviasi 14,244 dan nilai "Sig (2-tailed)" yaitu $\mathrm{p}=0,000$, artinya ada perbedaan yang signifikan pada tingkat stres mahasiswa tingkat akhir sebelum dan setelah dilakukan tafakur alam dan muhasabah. Apabila dibandingkan efektivitas di antara keduanya, dapat disimpulkan bahwa muhasabah lebih tinggi penurunan tingkat stresnya dibandingkan tafakur alam. Saran dari penelitian ini adalah diharapkan agar mahasiswa selalu melakukan introspeksi serta mawas diri sebagai bentuk muhasabah terhadap diri sendiri sehingga dapat terbuka pikiran dan wawasannya serta dapat mengontrol diri agar terhindar dari stres.
\end{abstract}

Kata Kunci: Stres, Muhasabah, Tafakur Alam

\section{The Effectiveness of Muhasabah and Tafakur Alam towards the Decrease of Stress Level in Final Level Student}

\begin{abstract}
Thesis for students is an obligation that must be completed, but the thesis is not as easy as doing paper or course tasks in general. Many things that can be an obstacle to be able to complete the thesis, so that makes students feel burdened and become stressful. This study used a quasi-experimental study design. The samples were students in a last year students and writing their undergraduate thesis totally 38 students. Using DASS (Depression Anxiety Stress Scale) questionnaire with the paired $t$ test. Based on the research results obtained there was difference between the mean values before and after muhasabah and tafakur alam that the mean of muhasabah was 21,789 and "Sig (2-tailed) was p=0,000. As well tafakur alam, there was difference between the mean values before and after tafakur alam was 21,211 and "Sig (2-tailed) was $p=0,000$, and it can be concluded that there was a significant differences of stress level of the students before and after muhasabah and tafakur alam. The effectiveness of both can be concluded that muhasabah is more effective reducing stress lever than tafakur alam. Suggestions from this research is expected that students always do introspection and introspection as a form of muhasabah to themselves so that it can open they mind and can control themselves to avoid the stress.
\end{abstract}

Keyword: Stress, Muhasabah, Tafakur Alam 


\section{Pendahuluan}

World Health Organization ${ }^{1}$ menyatakan stres merupakan masalah kesehatan masyarakat nomor empat di dunia dan akan menjadi nomor dua pada tahun 2020. Prevalensi penduduk yang mengalami stres emosional secara nasional adalah 6,0\% (37.728 orang dari 703.946 orang yang dianalisis). Provinsi dengan prevalensi stres emosional tertinggi adalah Sulawesi Tengah $(11,6 \%)$, sedangkan yang terendah di Lampung (1,2\%). Prevalensi stres emosional untuk wilayah Sulawesi Selatan sendiri sekitar 9,3\% dari subjek yang dianalisis. ${ }^{2}$

Dalam dunia pendidikan antara motivasi dan belajar merupakan dua istilah yang tidak dapat dipisahkan bahkan selalu berkaitan, sehingga karena eratnya seakan - akan tidak ada aktivitas belajar jika tidak memiliki motivasi. Sebab Motivasi merupakan dorongan yang terdapat dalam diri seseorang untuk berusaha mengadakan perubahan tingkah laku yang lebih baik dalam memenuhi kebutuhannya. ${ }^{3}$

Pentingnya motivasi karena motivasi adalah hal yang menyebabkan, menyalurkan dan mendukung perilaku manusia supaya mau bekerjasama secara giat sehingga mencapai hasil yang optimal. Kurangnya motivasi belajar. Sering kali mahasiswa tingkat akhir mengalami suatu fenomena berkurangnya motivasi belajar lebih spesifik dalam pembuatan skripsi dikarenakan karena stres. Stres ini dipicu karena beban belajar dan tugas skripsi yang cukup besar. Stres yang terjadi ketika seseorang mengalami suatu tekanan-tekanan dan ketidaknyamanan saat belajar bisa disebut dengan stres dalam belajar. ${ }^{4}$ Stres dalam belajar adalah perasaan yang dihadapi oleh seseorang ketika ada tekanan-tekanan terhadapnya. Tekanan - tekanan yang dimaksud adalah berhubungan dengan belajar dan kegiatan sekolah, misalnya saja tenggang waktu tugas, saat menjelang ujian, dan hal-hal yang lain.

Skripsi bagi mahasiswa adalah suatu kewajiban yang harus diselesaikan dalam jangka waktu yang sesingkat mungkin. Semakin cepat menyelesaikan skripsi dan di wisuda, semakin besar pula peluang untuk segera mencari pekerjaan. Namun, menyelesaikan sebuah skripsi tidaklah semudah mengerjakan makalah ataupun tugas- tugas mata kuliah pada umumnya. Banyak hal yang dapat menjadi kendala untuk mampu menyelesaikan skripsi, sehingga membuat mahasiswa merasa terbebani dan menjadi stres. ${ }^{5}$ Ada beberapa masalah yang muncul dan menghambat penyelesaian skripsi atau bahkan sampai menghentikan proses penyelesaian skripsi tersebut. Beberapa gambaran menunjukkan indikasi stres bahkan stres dialami oleh mahasiswa yang mengerjakan skripsi.

Selain motivasi, tafakur alam juga merupakan hal penting dalam menunjang kesehatan psikologis. Tafakur menurut bahasa berarti menghadap, kebalikan membelakangi. Tafakur menurut ahli bahasa Arab adalah memikirkan. Maka, tafakur bisa berarti 
memikirkan akibat dari sesuatu atau memikirkan maksud akhir dari sesuatu. Sedangkan, tafakur menurut istilah adalah "penelaahan universal yang bisa mengantarkan kepada pemahaman optimal dari maksud suatu perkataan“. Tafakur alam merupakan sarana pembelajaran untuk lebih mengenal ke Maha Besaran Allah SWT yang telah menciptakan langit dan bumi serta segala isinya. Tafakur alam dapat membuat seseorang mampu memahami tanda-tanda dan bukti-bukti kekuasaan sang Pencipta. Melalui tafakur alam seseorang juga dapat mengetahui bahwa semua di alam ini diciptakan tidak dengan sia-sia, dan mampu memahami kekuasaan dan kesempurnaan ciptaan Allah di segala penjuru. Pemahaman ini pada akhirnya menghantarkannya pada penyerahan diri, ketundukan dan rasa takut kepada-Nya sehingga menimbulkan ketenangan dari sisi psikologis.

Muhasabah dapat diartikan sebagai perenungan diri untuk mengetahui dan menghitung apa yang telah dilakukan sebelum Allah SWT menghisab amal seseorang pada hari pembalasan nantinya. Merenung disini merupakan suatu upaya seseorang untuk melakukan suatu perubahan yaitu: introspeksi diri/mawas diri terhadap sesuatu hal yang telah mereka lakukan dalam kehidupannya, sehingga seseorang mampu melakukan suatu perbaikan, dan peningkatan secara maksimal. Yang dimaksud Perenungan disini bukan hanya sekedar merenung saja, akan tetapi seseorang benar-benar mampu melakukan suatu perubahan /proses perbaikan/peningkatan prestasi sehingga seseorang bisa menciptakan pribadi yang unggul terhadap dirinya. ${ }^{6}$

Stres yang dihadapi mahasiswa ketika menghadapi penyusunan skripsi sering terjadi. Padahal stres tersebut dapat membuat penyusunan skripsi menjadi terhambat. Dengan adanya kontrol diri (Muhasabah) dan Mentafakuri ciptaan Allah SWT, diharapkan para mahasiswa bisa menumbuhkan motivasi belajar pada dirinya sehingga mereka bisa mengontrol sress yang acap kali mahasiswa hadapi. Karena pada dasarnya kontrol diri ini sangat penting dalam suatu kehidupan. Diperlukannnya suatu intervensi untuk mengontrol stres pada mahasiswa tingkatr akhir. Dari latar belakang diatas maka peneliti ingin mengetahui pengaruh muhasabah dan tafakur alam terhadap tingkat stres pada mahasiswa tingkat akhir FKK UMJ.

\section{Metode Penelitian}

Penelitian ini menggunakan desain studi quasi eksperimental dimana variabel dependen adalah tingkat stres, sedangkan variabel independen pada penelitian ini adalah muhasabah dan tafakur alam. Dan pada penelitian ini pula peneliti mengadakan pengamatan langsung terhadap satu kelompok subjek yang diberikan perlakuan / intervensi dengan dilakukan pengukuran sebelum dan sesudah perlakuan tanpa adanya kelompok pembanding, sehingga setiap subjek merupakan kelas control atas dirinya sendiri, hal ini disebut 
penelitian one group pretest posttest design. Intervensi dilaksanakan dua kali yaitu intervensi pertama pada hari Jumat, tanggal 10 Juni 2016 bertempat di rumah peneliti dan intervensi kedua diadakan pada tanggal 9 \& 10 Juli 2016 di Lembang Bandung. Sampel dalam penelitian ini adalah sebanyak 38 orang dengan kriteria inklusi yaitu mahasiswa semester 8 yang sudah mengerjakan skripsi sampai minimal bab pembahasan.

\section{Hasil}

Tabel 1. Karakteristik Responden

\begin{tabular}{lcc}
\hline Variabel & n & \% \\
\hline Umur & 1 & 2.63 \\
20 & 17 & 44.74 \\
21 & 17 & 44.74 \\
22 & 3 & 7.89 \\
23 & & \\
Umur & 18 & 47.40 \\
$\leq 21$ & 20 & 52.60 \\
$\geq 22$ & & \\
Jenis Kelamin & 31 & 81.60 \\
Perempuan & 7 & 18.40 \\
laki-laki &
\end{tabular}

Dari Tabel 1 dapat terlihat bahwa rata-rata umur responden adalah 21,58 tahun, median 22 tahun dengan standard deviasi 0,683 tahun. Umur termuda adalah 20 tahun dan umur tertua adalah 23tahun.Kelompok umur responden adalah $47,4 \%$ atau 18 orang yang berumur dibawah 21 tahun. Sedangkan kelompok umur yang berusia diatas 22 tahun adalah 52,6\% atau 20 orang dan jenis kelaminresponden adalah $81,6 \%$ atau 31 orang yang berjenis kelamin perempuan dan $18,4 \%$ atau 7 orang yang berjenis kelamin laki-laki. Hal ini menunjukkan bahwa responden mayoritas berjenis kelamin perempuan.

Tabel 2 menunjukkan bahwa tingkat stres rendah dan stres tinggi pada responden dengan usia >21 tahun yaitu berjumlah 20 responden, dimana 8 orang atau $21,1 \%$ mengalami stres rendah dan 12 orang atau $31,6 \%$ mengalami stres tinggi. Dan juga untuk usia $\leq 21$ tahun yang berjumlah 18 responden, 12 responden diantaranya atau 31,6\% mengalami stres rendah dan 6 responden lainnya atau $15,8 \%$ mengalami stres tinggi. Dari tabel 5.8 dapat dilihat bahwa tidak ada hubungan antara usia dengan tingkat stres mahasiswa tingkat akhir dengan $p$ value yaitu 0,119 atau ( $p$ value $>0,005)$.

Tabel 2. Hubungan Usia dengan Tingkat Stres

\begin{tabular}{|c|c|c|c|c|c|c|c|}
\hline \multirow{3}{*}{ Usia } & \multicolumn{4}{|c|}{ Tingkat Stres } & \multirow{2}{*}{\multicolumn{2}{|c|}{$\begin{array}{c}\text { Jumlah } \\
(\%)\end{array}$}} & \multirow{2}{*}{$\begin{array}{c}P \\
\text { Value }\end{array}$} \\
\hline & \multicolumn{2}{|c|}{ Rendah } & \multicolumn{2}{|c|}{ Tinggi } & & & \\
\hline & $\mathbf{n}$ & $\%$ & $\mathbf{n}$ & $\%$ & $\mathrm{n}$ & $\%$ & \multirow{4}{*}{0,119} \\
\hline $\begin{array}{l}\leq 21 \\
\text { tahun }\end{array}$ & 12 & 31,6 & 6 & 15,8 & 18 & 47,4 & \\
\hline $\begin{array}{l}>21 \\
\text { tahun }\end{array}$ & 8 & 21,1 & 12 & 31,6 & 20 & 52,6 & \\
\hline Total & 20 & 52,6 & 18 & 47,4 & 38 & 100 & \\
\hline
\end{tabular}

Tabel 3 menunjukkan bahwa jumlah responden laki-laki yang mengalami stres rendah adalah 2 responden atau 5,3\% dan stres tinggi yaitu 5 responden atau $13,2 \%$. Sedangkan responden perempuan yang mengalami stres rendah berjumlah 18 responden atau 47,4\% dan stres tinggi berjumlah 13 responden atau 34,2\%. Dari tabel 5.9 dapat dilihat bahwa tidak ada hubungan antara jenis kelamin dengan tingkat 
stres dengan $p$ value 0,222 ( $p$ value $>0,005)$.

Tabel 3. Hubungan Jenis Kelamin dengan Tingkat Stres

\begin{tabular}{|c|c|c|c|c|}
\hline \multirow[b]{2}{*}{$\begin{array}{c}\text { Jenis } \\
\text { Kelamin }\end{array}$} & \multicolumn{2}{|c|}{ Tingkat Stres } & \multirow[b]{2}{*}{$\begin{array}{c}\text { Jumlah } \\
(\%)\end{array}$} & \multirow[b]{2}{*}{$\begin{array}{c}p \\
\text { value }\end{array}$} \\
\hline & $\begin{array}{c}\text { Stres } \\
\text { Rendah }\end{array}$ & $\begin{array}{c}\text { Stres } \\
\text { Tinggi }\end{array}$ & & \\
\hline Laki-Laki & $\begin{array}{c}2 \\
(5,3 \%)\end{array}$ & $\begin{array}{c}5 \\
(13,2 \%)\end{array}$ & $\begin{array}{c}7 \\
(18,4 \%)\end{array}$ & \\
\hline Perempuan & $\begin{array}{c}18 \\
(47,4 \%)\end{array}$ & $\begin{array}{c}13 \\
(34,2 \%)\end{array}$ & $\begin{array}{c}31 \\
(81,6 \%)\end{array}$ & 0,222 \\
\hline Total & $\begin{array}{c}20 \\
(52,6 \%)\end{array}$ & $\begin{array}{c}18 \\
(47,4 \%)\end{array}$ & $\begin{array}{c}38 \\
(100 \%)\end{array}$ & \\
\hline
\end{tabular}

\section{Uji Paired T-Test}

\section{Hasil Paired T-Test Muhasabah}

Penelitian ini menggunakan rumus paired t-test dikarenakan data berdistribusi normal. Berikut ini adalah hasil perhitungan paired $t$ test Muhasabah:

Tabel 4. Hasil Paired T-Test Muhasabah

\begin{tabular}{lcccccc}
\hline Variabel & Mean & SD & SE & t & $\begin{array}{c}\text { Sig. 2 } \\
\text { tailed }\end{array}$ & N \\
& & & & & & \\
\hline Pretetst- & 21,789 & 14,148 & 2,295 & 9,494 & 0,000 & 38 \\
Posttest & & & & & & \\
\hline
\end{tabular}

Setelah dilakukan uji paired t-test, terlihat perbedaan nilai mean antara sebelum dilakukan muhasabah dan sesudah dilakukan muhasabah yaitu dengan nilai mean 21,789 dengan standar deviasi 14,148 . Selain itu didapatkan pula hasil nilai p yang dapat dilihat pada "Sig (2-tailed)" yaitu $\mathrm{p}=0,000$, maka dapat disimpulkan ada perbedaan yang signifikan pada tingkat stres mahasiswa tingkat akhir sebelum dilakukan muhasabah dan setelah dilakukan
muhasabah.Nilai t hasil hitung sebesar 9,494, jika dibandingkan dengan $\mathrm{t}$ pada tabel uji $\mathrm{t}$ dengan df 37 dan derajat signifikansi 5\%, maka nilai t uji lebih besar dari t tabel dan hal ini menunjukkan $\mathrm{Ha}$ diterima, sedangkan Ho ditolak.

\section{Hasil Paired T-Test Tafakur Alam}

Setelah dilakukan uji paired $t$-test, terlihat perbedaan nilai mean antara sebelum dilakukan tafakur alam dan sesudah dilakukan tafakur alam yaitu dengan nilai mean 21,211 dengan standar deviasi 14,224. Selain itu didapatkan pula hasil nilai $\mathrm{p}$ yang dapat dilihat pada "Sig (2-tailed)" yaitu $\mathrm{p}=0,000$, maka dapat disimpulkan ada perbedaan yang signifikan pada tingkat stres mahasiswa tingkat akhir sebelum dilakukan tafakur alam dan setelah dilakukan tafakur alam. Nilai $\mathrm{t}$ hasil hitung sebesar 9,192, jika dibandingkan dengan $\mathrm{t}$ pada tabel uji $\mathrm{t}$ dengan $\mathrm{df}$ 37 dan derajat signifikansi 5\%, maka nilai t uji lebih besar dari t tabel dan hal ini menunjukkan Ha diterima, sedangkan Ho ditolak.

Tabel 5. Hasil Paired T-Test Tafakur Alam

\begin{tabular}{llccccc}
\hline Variabel & Mean & SD & SE & $\mathrm{t}$ & $\begin{array}{l}\text { Sig. 2 } \\
\text { tailed }\end{array}$ & $\mathrm{N}$ \\
& & & & & & \\
\hline $\begin{array}{l}\text { Pretetst- } \\
\text { Posttest }\end{array}$ & 21,211 & 14,244 & 2,307 & 9,192 & 0,000 & 38 \\
\hline
\end{tabular}

\section{Pembahasan}

Hasil penelitian menunjukkan dari 38 responden, kelompok umur responden yang berumur dibawah 21 tahun ada 18 orang atau 
47,4\% sedangkan kelompok umur diatas 22 tahun ada 20 orang atau $52,6 \%$. Sebagaimana diketahui bahwa responden dalam penelitian ini merupakan mahasiswa regular tingkat akhir angkatan 2012, yang pada umumnya, tahun kelahiran mahasiswa regular 2012 adalah pada tahun 1994 dimana pada tahun ini rata-rata umurnya adalah lebih dari 22 tahun. Menurut jenis kelamin responden adalah $81,6 \%$ atau 31 orang yang berjenis kelamin perempuan dan $18,4 \%$ atau 7 orang yang berjenis kelamin lakilaki. Terlihat adanya perbedaan yang berarti antara jumlah responden perempuan dan lakilaki, hal ini dikarenakan distribusi jumlah mahasiswa yang berjenis kelamin perempuan lebih besar dari laki-laki.

\section{Hubungan Umur dengan Tingkat Stres}

Hasil penelitian menunjukkan bahwa tidak ada hubungan antara usia dengan tingkat stres mahasiswa tingkat akhir dengan $p$ value yaitu 0,119 atau ( $p$ value> 0,005). Hal ini disebabkan karena sampel yang digunakan homogeny. Pengelompokan usia yang digunakan pada penelitian ini terlalu dekat yang berada pada rentang usia dewasa awal. Sebagaimana dijelaskan oleh Potter dan Perry 2005 dalam Jemirda Sundari bahwa rentang usia 21 sampai 27 tahun merupakan awal memasuki dunia kedewasaan. $^{7}$ Lain halnya dengan pengelompokan usia yang digunakan berdasarkan tingkat perkembangannya. Perkembangan merupakan stressor psikososial, apabila tidak dijalani dengan baik (tidak mampu beradaptasi) maka akan menimbulkan stres pada orang tersebut. ${ }^{8}$

\section{Hubungan Jenis Kelamin dengan Tingkat Stres}

Hasil penelitian menunjukkan bahwa tidak ada hubungan antara jenis kelamin dengan tingkat stres dengan $p$ value 0,222 ( $p$ value $>0,005$ ). Hal ini dikarenakan adanya perbedaan jumlah seluruh responden yang cukup mencolok antara perempuan dan laki-laki.

\section{Pengaruh Muhasabah terhadap Penurunan Tingkat Stres Mahasiswa}

Berdasarkan hasil penelitian, didapatkan perbedaan nilai mean antara sebelum dilakukan muhasabah dan sesudah dilakukan muhasabah yaitu dengan nilai mean 21,789 dengan standar deviasi 14,148. Selain itu didapatkan pula hasil nilai p yang dapat dilihat pada "Sig (2-tailed)" yaitu $\mathrm{p}=0,000$, maka dapat disimpulkan ada perbedaan yang signifikan pada tingkat stres mahasiswa tingkat akhir sebelum dilakukan muhasabah dan setelah dilakukan muhasabah.

\section{Pengaruh Tafakur Alam terhadap Penurunan Tingkat Stres Mahasiswa}

Tidak jauh berbeda dengan hasil penelitian muhasabah. Hasil penelitian tafakur alam juga didapatkan perbedaan nilai mean antara sebelum dilakukan tafakur alam dan sesudah dilakukan tafakur alam yaitu dengan nilai mean 21,211 dengan standar deviasi 14,224. Selain itu didapatkan pula hasil nilai $p$ 
yang dapat dilihat pada "Sig (2-tailed)" yaitu $\mathrm{p}=0,000$, maka dapat disimpulkan ada perbedaan yang signifikan pada tingkat stres mahasiswa tingkat akhir sebelum dilakukan tafakur alam dan setelah dilakukan tafakur alam.

\section{Efektivitas antara Muhasabah dan Tafakur} Alam dalam Penurunan Stres pada

\section{Mahasiswa Tingkat Akhir}

Berdasarkan hasil uji paired $t$ test didapatkan nilai $\mathrm{t}$ hitung pada muhasabah sebesar 9,494 dan t hitung pada tafakur alam sebesar 9,192 dengan df 37 dan signifikansi 5\%. Jika dibandingkan dengan $\mathrm{t}$ pada tabel uji $\mathrm{t}$ dengan df 37 dan signifikansi 5\% adalah 2,026. Semakin lebih besar nilai $t$ hitung dibanding $t$ tabel maka Ho ditolak atau semakin efektif, semakin kecil nilai $\mathrm{t}$ hitung dibanding $\mathrm{t}$ tabel maka Ho diterima atau semakin tidak efektif. Maka jika dibandingkan antara muhasabah dan tafakur alam, muhasabah lebih efektif dalam menurunkan tingkat stres pada mahasiswa dibandingkan tafakur alam. Karena nilai t hitung tmuhasabah lebih besar dari t tabel dan t hitung tafakur alam.

Stres pada mahasiswa tingkat akhir pada dasarnya merupakan hal yang biasa terjadi. Mengingat bahwa mahasiswa merupakan sumber daya potensial yang nantinya akan menjadi tenaga kerja di perusahaan, tingkat stres yang tinggi akan berdampak pula pada kemampuan mengerjakan pekerjaannya nanti. Menurut Rettob ${ }^{9}$, faktor-faktor penyebab stres dapat dibedakan menjadi dua, yaitu faktor internal dan eksternal. Faktor internal yaitu berupa kondisi tubuh/fisik dan konflik pribadi sedangkan faktor eksternal seperti keluarga yang kurang harmonis, masalah ekonomi, dan sebagainya. Selain itu menurut Alvin ${ }^{4}$, stressor internal dapat berasal dari diri sendiri yaitu berupa pikiran-pikiran negatif, keyakinan dalam diri, dan kepribadian yang dimiliki.

Dalam penelitian ini, peneliti bermaksud untuk memasuki alam internal mahasiswa tingkat akhir, dimana peneliti melakukan muhasabah dan tafakur alam terhadap mahasiswa tersebut supaya mahasiswa dapat melakukan berbagai macam introspeksi diri ataupun mawas diri terhadap sesuatu hal yang telah mereka lakukan dalam kehidupannya, mengenal siapa dirinya, diciptakan dengan tujuan apa dan kepada siapa tempat kembali dirinya, sehingga nantinya mereka akan dapat melakukan suatu perbaikan dan peningkatan secara maksimal serta dapat menciptakan pribadi yang unggul terhadap dirinya dan terutama dapat lebih fokus dalam mengerjakan skripsi tanpa stres. Hal tersebut dapat dibuktikan dengan hasil penelitian ini, dimana kedua intervensi baik muhasabah maupun tafakur alam memberikan perbedaan yang signifikan antara tingkat stres mahasiswa sebelum dan sesudah diberi muhasabah dan tafakur alam. Bahkan perbedaan nilai tafakur alam jauh lebih signifikan dibandingkan muhasabah. 


\section{Daftar Pustaka}

1. WHO. Work Organization \& Stress, (Switzerland: WHO, 2013).

2. Depkes. Riset Kesehatan Dasar 2013. (Jakarta: Badan Penelitian dan Pengembangan Kesehatan Kementerian Kesehatan RI, 2013).

3. Hamzah BU. Teori Motivasi dan Pengukurannya, (Jakarta: PT Bumi Aksara, 2007).

4. Alvin. Mengatasi Stres Belajar. (Jakarta. Elex Media Komputindo, 2007).

5. Fadillah. Stres dan Motivasi Belajar Pada Mahasiswa Psikologi Universitas Mulawarman yang Sedang Menyusun Skripsi. (Journal Psikologi, 1 (3): 254- ISSN 0000-0000, 2013).

6. Saifuddin B, Manajemen Muhasabah Diri, (Bandung: Mizan Pustaka, 2011).

7. Jemirda Sundari. Hubungan Antara Stress dengan Intensitas Olahraga pada Mahasiswa Reguler 2008 Fakultas Matematika dan Ilmu Pengetahuan Alam Universitas Indonesia. (Skripsi Jurusan Fakultas Ilmu Keperawatan Universitas Indonesia Depok, 2012).

8. Hawari D. Manajemen stres, cemas, dan depresi. (Jakarta: Fakultas Kedokteran Universitas Indonesia, 2001).

9. Rettob, Identifikasi Faktor-Faktor Penyebab Stres Terhadap Stres Mahasiswa yang Sedang Menempuh Skripsi di Universitas Katolik Soegijapranata: Studi Kasus pada Mahasiswa Fakultas Ekonomi Jurusan Manajemen dan Jurusan Akuntansi Universitas Katolik Soegijapranata Semarang. Semarang: (Skripsi Jurusan Manajemen Fakultas Ekonomi Universitas Katolik Soegijapranata Semarang, 2008). 